\title{
Anion Proportion in the Nutrient Solution Impacts the Growth and Nutrient Status of Anthurium (Anthurium andraeanum Linden ex.
André.)
}

\author{
Viviana P. Sosa-Flores and Luis A. Valdez-Aguilar ${ }^{1}$ \\ Departamento de Horticultura, Universidad Autónoma Agraria Antonio \\ Narro, Calzada Antonio Narro 1923, Buenavista, Saltillo, Coah., México \\ 25315 \\ Donita L. Cartmill and Andrew D. Cartmill \\ School of Agriculture, University of Wisconsin-Platteville, 1 University \\ Plaza, Platteville, WI 53818
}

Adalberto Benavides-Mendoza

Departamento de Horticultura, Universidad Autónoma Agraria Antonio Narro, Calzada Antonio Narro 1923, Buenavista, Saltillo, Coah., México 25315

\begin{abstract}
Antonio Juárez-Maldonado
Departamento de Botánica, Universidad Autónoma Agraria Antonio Narro, Calzada Antonio Narro 1923, Buenavista, Saltillo, Coah., México 25315
\end{abstract}

Additional index words. tropical ornamental plants, nitrate, sulfate, phosphate, mixture experiments

\begin{abstract}
Anthurium is native to habitats characterized by low nutrient supply; however, when cultivated, it demands a complete fertilization program. The objective of the present study was to determine the effect of varying proportions of anions [nitrate $\left(\mathrm{NO}_{3}{ }^{-}\right)$, phosphate $\left(\mathrm{H}_{2} \mathrm{PO}_{4}{ }^{-}\right)$, and sulphate $\left.\left(\mathrm{SO}_{4}{ }^{2-}\right)\right]$ in the nutrient solution on the growth and nutrient status of container-grown anthurium. The effect of the anion proportion was modeled using mixture analysis. Plant growth increased when fertigated with solutions containing an anion proportion of $0.78: 0.12: 0.10,0.20: 0.12: 0.68$, and $0.80: 0.02: 0.18$. The contour plots showed that optimum response may be achieved in two areas, an area with high $\mathrm{NO}_{3}{ }^{-}$proportion $(0.50-0.80)$ and an area with high $\mathrm{SO}_{4}{ }^{-}$, provided $\mathrm{H}_{2} \mathrm{PO}_{4}{ }^{-}$was high $\left(0.09-0.12\right.$ for $\mathrm{H}_{2} \mathrm{PO}_{4}{ }^{-}$ and $0.55-0.70$ for $\mathrm{SO}_{4}{ }^{2-}$ ). The counter plots indicate that high $\mathrm{SO}_{4}{ }^{2-}$ proportions combined with low $\mathrm{NO}_{3}{ }^{-}$and $\mathrm{H}_{2} \mathrm{PO}_{4}{ }^{-}$were detrimental and that optimum growth depends not only on nitrogen $(\mathrm{N})$ concentration, as it may be attained at either high or low $\mathrm{NO}_{3}{ }^{-}$. Nitrogen and sulfur $(S)$ concentration was higher in plants fertigated with high $\mathrm{NO}_{3}{ }^{-}(0.55-0.80)$ and $\mathrm{SO}_{4}{ }^{2-}$ $(0.40-0.70)$ solutions. Shoot $P$ was higher when plants were fertigated with solutions of low (as long as $\mathrm{NO}_{3}{ }^{-}$was at proportion of 0.50 and $\mathrm{SO}_{4}{ }^{2-}$ at 0.35 ) or high $\mathrm{H}_{2} \mathrm{PO}_{4}{ }^{-}$proportions (as long as $\mathrm{SO}_{4}{ }^{2-}$ proportion was at 0.35 ). At low concentration of $\mathrm{S}$ in the shoot, increasing $\mathrm{S}$ resulted in increasing shoot $\mathrm{N}$; however, further $\mathrm{S}$ increments in the shoot were associated with a decrease in $\mathrm{N}$. Plants fertigated with the highest proportion of $\mathrm{H}_{2} \mathrm{PO}_{4}^{-}$resulted in the lowest $\mathrm{S}$ concentrations despite some solutions contained high $\mathrm{SO}_{4}{ }^{2-}$, suggesting that $\mathrm{H}_{2} \mathrm{PO}_{4}{ }^{-}$ counteracted the uptake of $\mathrm{SO}_{4}{ }^{2-}$. Nitrogen and $\mathrm{S}$ were predominantly diverted to the roots in control plants; however, when plants were fed with both high $\mathrm{SO}_{4}{ }^{2-}$ and high $\mathrm{H}_{2} \mathrm{PO}_{4}{ }^{-}$ solutions, even more $S$ was allocated to the roots, which explains the increased shoot growth due to the lower $S$ concentrations. In conclusion, the increased growth of anthurium was attained at either high or low $\mathrm{NO}_{3}{ }^{-}$proportion and it is able to cope with high $\mathrm{SO}_{4}{ }^{2-}$ by avoiding the transport of $\mathrm{S}$ to the shoot, decreasing $\mathrm{SO}_{4}{ }^{2-}$ intake, maintaining a favorable internal $N / S$ and $S / P$ proportion, and increasing $P$ tissue concentration.
\end{abstract}

Anthurium (Anthurium andraeanum Linden ex. André.) is a tropical ornamental species of considerable beauty, which is cultivated for

Received for publication 4 May 2017. Accepted for publication 11 Sept. 2017.

${ }^{1}$ Corresponding author. E-mail: luisalonso.valdez@ uaaan.mx. both the cut flower and potted plant markets. In its natural habitat, anthurium is considered an epiphytic or lithophytic species (Hull and Henny, 1995) and is usually found in habitats characterized by low light levels and low nutrient supply, typically in shaded conditions and on the trunks of trees, where the roots have no contact with the soil (Zotz and Hietz, 2001). Nutrients supply and availability, particularly $\mathrm{N}$, have been reported to be key factors for anthurium growth, flower number, and quality/marketability (Chang et al., 2010).

Nitrogen is a major element in determining final quality of anthurium plants (Conover and Henny, 1995). In some species of anthurium, including Anthurium acaule and Anthurium cordatum, similar N concentrations to that of terrestrial species have been reported, $1.87 \%$ and $2.33 \%$, respectively (Zotz and Hietz, 2001). Li and Zhang (2002) reported high quality and maximum dry weight of anthurium plants fed with $\mathrm{N}$ concentrations ranging from 10 to $40 \mathrm{mg} \cdot \mathrm{L}^{-1}$, with $20 \mathrm{mg} \cdot \mathrm{L}^{-1} \mathrm{~N}$ producing the highest quality.

Nonetheless, the interaction of $\mathrm{N}$ with other nutrients must also be considered when developing a feasible fertility program as $\mathrm{N}$ may affect the availability and uptake of other ions. For example, it has been reported that high quality in $A$. andraeanum is obtained when fertilized at low N (1.85 g per $15-\mathrm{cm}$ pot per year) and high potassium $(\mathrm{K})$ (1.39-3.07 g per $15-\mathrm{cm}$ pot per year) rates; conversely, plants fertilized with high $\mathrm{N}$ and $\mathrm{K}$ rates resulted in poor growth and marketability (Conover and Henny, 1995). Similarly, rapid growth was reported in anthurium when $\mathrm{N}$ and $\mathrm{K}$ were supplied at 8.9 and $3.2 \mathrm{mmol} \cdot \mathrm{L}^{-1}$, respectively; however, when $\mathrm{Ca}$ was reduced from 2.3 to 1.2 $\mathrm{mmol} \cdot \mathrm{L}^{-1}$, a decrease in the length of the vegetative phase was observed along with an increase in flower production (Dufour and Guérin, 2005).

Therefore, the total nutrient concentration and the proportion of the ions dissolved in the nutrient solution have to be considered (Steiner, 1968) when defining an optimum program of fertilization. The mutual ion relations are also important for plant growth as an unbalanced combination may result in decreased biomass and yield because of the antagonistic relationships (Ding et al., 2006; Jakobsen, 1993). There is limited information as to the effect of the nutrient proportions and interactions on the growth and marketability of anthurium; thus, the present study had the objective of determining the response of container-grown plants to varying proportions of anions [nitrate $\left(\mathrm{NO}_{3}^{-}\right)$, phosphate $\left(\mathrm{H}_{2} \mathrm{PO}_{4}^{-}\right)$, and sulphate $\left.\left(\mathrm{SO}_{4}{ }^{2-}\right)\right]$ in the nutrient solution.

\section{Materials and Methods}

Cultural conditions and plant material. The experiment was conducted in a greenhouse at the Universidad Autónoma Agraria Antonio Narro, in Saltillo, Coahuila, México $\left(25^{\circ} 21^{\prime} 24.37^{\prime \prime} \mathrm{N}\right.$ latitude, $101^{\circ} 02^{\prime} 05.45^{\prime \prime} \mathrm{W}$ longitude; $1762 \mathrm{~m}$ above sea level). Environmental parameters were recorded (Watch Dog 1000 Series, Spectrum Technologies, Inc., Aurora, IL) throughout the study, rendering an average daily temperature of $20^{\circ} \mathrm{C}$ (maximum $31.5{ }^{\circ} \mathrm{C}$, minimum $13.5{ }^{\circ} \mathrm{C}$ ), relative humidity $66 \% \pm 20 \%$, and 
photosynthetically active radiation $(P A R)$ at $177 \mu \mathrm{mol} \cdot \mathrm{m}^{-2} \cdot \mathrm{s}^{-1}$.

The growing medium consisted of a 1:1 mixture of sphagnum peat (PREMIER; Premier Tech, Toronto, Canada) $\left(\mathrm{NO}_{3}{ }^{-}: 0.15\right.$ meq. $\mathrm{L}^{-1}, \mathrm{H}_{2} \mathrm{PO}_{4}^{-}$: 0.08 meq. $\mathrm{L}^{-1}, \mathrm{SO}_{4}{ }^{2-}$ : 0.22 meq. $\mathrm{L}^{-1}, \mathrm{~K}^{+}: 0.15$ meq. $\mathrm{L}^{-1}, \mathrm{Ca}^{2+}: 1.18$ meq. $\mathrm{L}^{-1}, \mathrm{Mg}^{2+}: 0.55$ meq. $\mathrm{L}^{-1}, \mathrm{HCO}_{3}^{-}: 0.70$ meq. $\mathrm{L}^{-1}$ ) and horticultural-grade perlite (HORTIPERL; Termolita, Monterrey, México). The medium $\mathrm{pH}$ was adjusted to 6.3 before transplanting to $17.8-\mathrm{cm}$ black plastic standard pots. Anthurium andraeanum cv. Tropical plants (12-15 cm in height, with 2-3 young leaves) were transplanted into the medium on 17 Oct. 2014 and harvested on 20 Oct. 2015.

Table 1. Proportion of anions and cations in the nutrient solutions assessed. ${ }^{\mathrm{z}}$

\begin{tabular}{lcccccc}
\hline Nutrient solution & $\mathrm{NO}_{3}{ }^{-}$ & $\mathrm{H}_{2} \mathrm{PO}_{4}^{-}$ & $\mathrm{SO}_{4}{ }^{-2}$ & $\mathrm{~K}^{+}$ & $\mathrm{Ca}^{2+}$ & $\mathrm{Mg}^{2+}$ \\
\hline 1 & 0.43 & 0.05 & 0.52 & 0.42 & 0.25 & 0.33 \\
2 & 0.80 & 0.02 & 0.18 & 0.48 & 0.51 & 0.01 \\
3 & 0.78 & 0.12 & 0.10 & 0.08 & 0.59 & 0.33 \\
5 & 0.20 & 0.12 & 0.68 & 0.65 & 0.25 & 0.10 \\
5 & 0.49 & 0.12 & 0.39 & 0.09 & 0.68 & 0.23 \\
6 & 0.28 & 0.02 & 0.70 & 0.37 & 0.47 & 0.17 \\
7 & 0.36 & 0.10 & 0.55 & 0.22 & 0.57 & 0.21 \\
8 (Control) & 0.60 & 0.05 & 0.35 & 0.35 & 0.45 & 0.20 \\
\hline
\end{tabular}

${ }^{\mathrm{z}}$ Total sum of anions, and cations, was held constant at $20 \mathrm{meq} \cdot \mathrm{L}^{-1}$; thus, to determine the chemical composition of a given nutrient solution, each proportion should be multiplied by 20. For example, solution number 1 has $\mathrm{NO}_{3}{ }^{-}$at $0.43 \times 20=8.6 \mathrm{meq} \cdot \mathrm{L}^{-1}, \mathrm{H}_{2} \mathrm{PO}_{4}^{-}$at $0.05 \times 20=1.0 \mathrm{meq} \cdot \mathrm{L}^{-1}$ and $\mathrm{SO}_{4}{ }^{2-}$ at $0.52 \times 20=10.4 \mathrm{meq} \cdot \mathrm{L}^{-1}$.

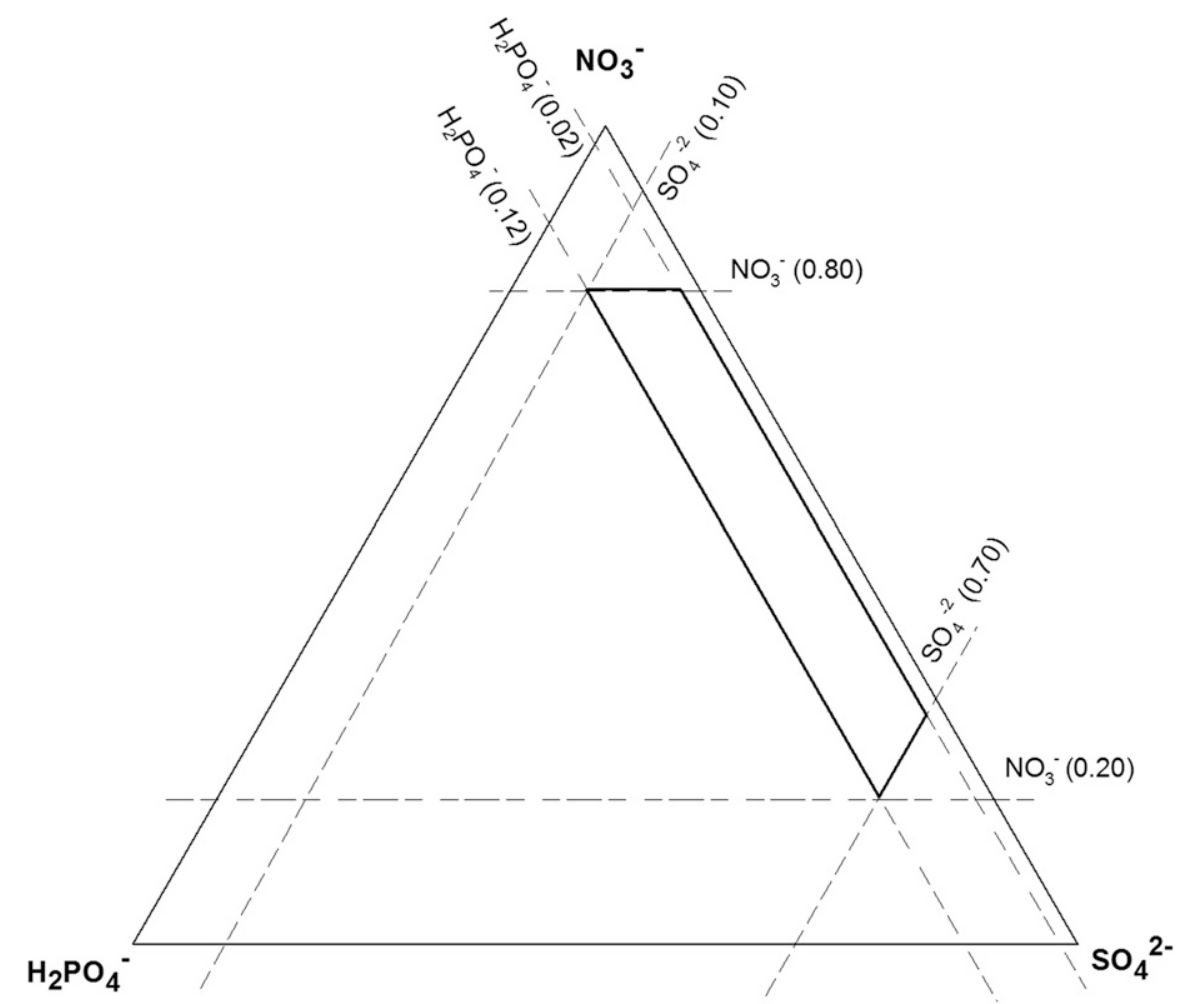

Fig. 1. Design points corresponding to the mixtures of $\mathrm{NO}_{3}{ }^{-}, \mathrm{H}_{2} \mathrm{PO}_{4}^{-}$, and $\mathrm{SO}_{4}{ }^{2-}$ the nutrient solutions. The lines demarcate the minimum and maximum proportion of each anion.

Nutrient solutions. The treatments consisted of eight nutrient solutions selected with Design Expert v. 9.0 (Stat Ease, Inc., Minneapolis, MN) (Table 1). Electrical conductivity (EC) and $\mathrm{pH}$ of the nutrient solutions was maintained at $2.0 \mathrm{dS} \cdot \mathrm{m}^{-1}$ and 5.5-6.0, respectively. The sum of anions in all the nutrient solutions was held constant at 20 meq. $\mathrm{L}^{-1}$. However, the proportions of $\mathrm{NO}_{3}{ }^{-}$, $\mathrm{H}_{2} \mathrm{PO}_{4}^{-}$, and $\mathrm{SO}_{4}{ }^{2-}$ varied from 0.20 to 0.80 , 0.02 to 0.12 , and 0.10 to 0.70 , respectively, to explore the area shown in Fig. 1. The control treatment corresponded to Steiner's formulation, containing (meq. $\left.\mathrm{L}^{-1}\right) 12 \mathrm{NO}_{3}^{-}, 1 \mathrm{H}_{2}$ $\mathrm{PO}_{4}^{-}, 7 \mathrm{SO}_{4}{ }^{2-}, 9 \mathrm{Ca}^{2+}, 7 \mathrm{~K}^{+}$, and $4 \mathrm{Mg}^{2+}$ (Steiner, 1973). Micronutrients in all the nutrient solutions were provided at the following concentrations $\left(\mathrm{mg} \cdot \mathrm{L}^{-1}\right)$ : 4 Fe-EDTA, 2 Mn-EDTA, 0.37 B, 0.32 Zn-EDTA, 0.16 $\mathrm{Cu}$-EDTA, and 0.11 Mo. Plants were manually irrigated when the growing medium registered a moisture tension of $10 \mathrm{cb}$ (Irrometer Model MLT; IRROMETER, Riverside, CA) adding enough solution to attain a leaching fraction of $\approx 30 \%$.

Assessment of plant growth and nutrient status. Plants were harvested $368 \mathrm{~d}$ after transplanting. Harvested plant material was separated into roots and shoots and rinsed twice with deionized water. Root volume was measured by the water displacement method in a graduated cylinder. Leaf area and spathe area were measured in an area meter (Model LI-3100C; LI-COR Inc., Lincoln, NE). Fresh weight of shoot and root were measured before drying in an oven at $70{ }^{\circ} \mathrm{C}$ for $3 \mathrm{~d}$. Dry tissues were then weighed and ground to pass a 40 mesh filter (Mini Willey Mill; Thomas Scientific, Swedesboro, NJ).

Nitrogen concentration in plant tissues was determined using semimicro Kjeldahl's procedure. Phosphorus $(\mathrm{P})$ and $\mathrm{S}$ concentrations were determined with inductively coupled plasma emission spectrometer (ICP-AES 725 Series Agilent; Mulgrave, Victoria, Australia) in samples digested in a mixture of $\mathrm{H}_{2} \mathrm{SO}_{4}$ and $\mathrm{HClO}_{4}$ plus $1 \mathrm{~mL}$ of $\mathrm{H}_{2} \mathrm{O}_{2}$ for $\mathrm{P}$ analysis and in a mixture of $\mathrm{HNO}_{3}$ and $\mathrm{HClO}_{4}$ for $\mathrm{S}$ analysis.

Statistical design and analysis. The eight nutrient solutions with four replications (one pot per replication) were distributed in a randomized complete block design. Data were analyzed with SAS to conduct an analysis of variance and a multiple comparison test (Duncan's procedure, $P<0.05$ ). The effect of the $\mathrm{NO}_{3}{ }^{-}: \mathrm{H}_{2} \mathrm{PO}_{4}{ }^{-}: \mathrm{SO}_{4}{ }^{2-}$ proportion was

Table 2. Effect of the $\mathrm{NO}_{3}{ }^{-}: \mathrm{H}_{2} \mathrm{PO}_{4}^{--}: \mathrm{SO}_{4}{ }^{2-}$ proportion in the nutrient solution on growth parameters of anthurium (Anthurium andraeanum Linden ex André) plants.

\begin{tabular}{|c|c|c|c|c|c|c|c|c|c|c|c|}
\hline $\mathrm{NO}_{3}{ }^{-}$ & $\frac{\mathrm{H}_{2} \mathrm{PO}_{4}^{-}}{\text {Proportion }}$ & $\mathrm{SO}_{4}^{2-}$ & $\begin{array}{c}\text { Spathe } \\
\text { area }\left(\mathrm{cm}^{2}\right)\end{array}$ & $\begin{array}{c}\text { Leaf } \\
\operatorname{area}\left(\mathrm{cm}^{2}\right)\end{array}$ & $\begin{array}{c}\text { Root } \\
\text { volume }\left(\mathrm{cm}^{3}\right)\end{array}$ & $\begin{array}{l}\text { Shoot } \\
\text { fresh wt (g) }\end{array}$ & $\begin{array}{c}\text { Root } \\
\text { fresh wt (g) }\end{array}$ & $\begin{array}{c}\text { Shoot } \\
\text { dry wt (g) }\end{array}$ & $\begin{array}{c}\text { Root } \\
\text { dry wt (g) }\end{array}$ & $\begin{array}{c}\text { Total } \\
\text { fresh wt }(\mathrm{g})\end{array}$ & $\begin{array}{c}\text { Total } \\
\text { dry wt }(\mathrm{g})\end{array}$ \\
\hline 0.80 & 0.02 & 0.18 & $145 \mathrm{abc}$ & $770 \mathrm{a}$ & $107 \mathrm{~b}$ & $83.5 \mathrm{a}$ & $91 \mathrm{abc}$ & $10.9 \mathrm{a}$ & $8.93 \mathrm{bc}$ & $178 \mathrm{ab}$ & $21.1 \mathrm{a}$ \\
\hline 0.20 & 0.12 & 0.68 & 169 a & $790 \mathrm{a}$ & $151 \mathrm{a}$ & $85.7 \mathrm{a}$ & $122 \mathrm{a}$ & $9.94 \mathrm{ab}$ & $12.7 \mathrm{a}$ & $208 \mathrm{a}$ & $21.5 \mathrm{a}$ \\
\hline 0.49 & 0.12 & 0.39 & $104 \mathrm{~cd}$ & $563 \mathrm{~b}$ & $75 \mathrm{c}$ & $60.6 \mathrm{ab}$ & $68 \mathrm{bcd}$ & $6.75 \mathrm{abc}$ & $7.55 \mathrm{~cd}$ & $129 b c$ & $15.4 \mathrm{~b}$ \\
\hline 0.28 & 0.02 & 0.70 & $149 \mathrm{abc}$ & $430 \mathrm{~b}$ & $52 \mathrm{~cd}$ & $36.9 \mathrm{bc}$ & $44 \mathrm{~d}$ & $8.33 \mathrm{abc}$ & $5.49 \mathrm{~d}$ & $81 \mathrm{c}$ & $11.5 \mathrm{~b}$ \\
\hline 0.36 & 0.10 & 0.55 & $62 \mathrm{de}$ & $410 \mathrm{~b}$ & $43 \mathrm{~d}$ & $47.7 \mathrm{bc}$ & $49 \mathrm{~cd}$ & $5.56 \mathrm{bc}$ & $6.17 \mathrm{~cd}$ & $97 \mathrm{c}$ & $10.9 \mathrm{~b}$ \\
\hline
\end{tabular}




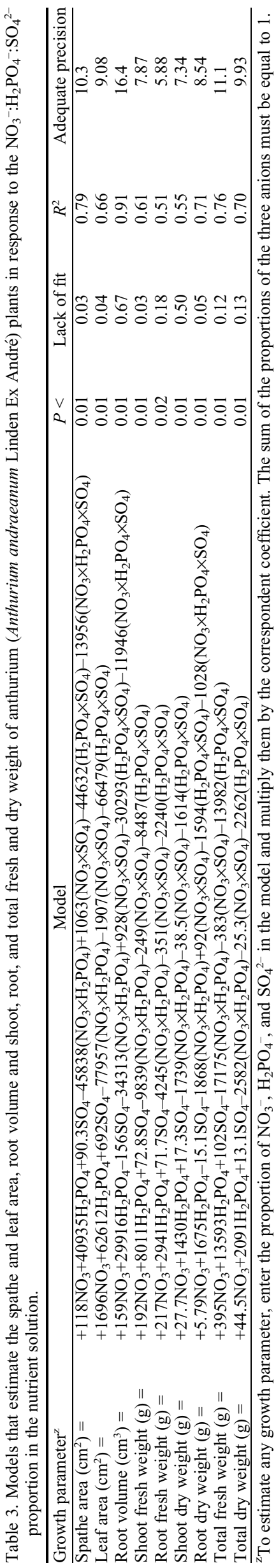

modeled using mixture analysis with DesignExpert $^{\circledR}$ v 9.0. The models selected were those with the highest $R^{2}$ and $P$ value, along with an adequate precision higher than 4.0 and a nonsignificant lack of fit, which indicates that the model can be used to predict the response of plants when used within the space on which it was designed (Fig. 1). A regression analysis was conducted when a significant response of plant growth or nutrient concentration in plant tissues was detected.

\section{Results and Discussion}

Growth and biomass. Growth was increased when plants were fertigated with solutions containing a $\mathrm{NO}_{3}^{-}: \mathrm{H}_{2} \mathrm{PO}_{4}^{-}: \mathrm{SO}_{4}{ }^{2-}$ proportion of 0.78:0.12:0.10, 0.20:0.12:0.68, and 0.80:0.02:0.18; in general, all parameters measured were significantly higher when compared with plants fertigated with Steiner's nutrient solution (Table 2).

Mixture analysis allowed the identification of several parameters whose models can be used to explore the space area designed (Table 3). The integration of the predictions of each individual model allows the definition of specific areas in the contour plots that include the nutrient solutions on which a threshold optimum response may be achieved; in the present study, there were two areas of the explored space for highest leaf area (Fig. 2) and shoot, root, and total fresh (Fig. 3) and dry weight (Fig. 4):

a) An area with high proportions of $\mathrm{NO}_{3}^{-}$: $0.50-0.80$ for $\mathrm{NO}_{3}{ }^{-}, 0.02-0.06$ for $\mathrm{H}_{2} \mathrm{PO}_{4}{ }^{-}$, and $0.10-0.35$ for $\mathrm{SO}_{4}{ }^{2-}$.

b) An area with high proportions of $\mathrm{SO}_{4}$ but provided the proportion of $\mathrm{H}_{2} \mathrm{PO}_{4}^{-}$was high: $0.20-0.35$ for $\mathrm{NO}_{3}{ }^{-}, 0.09-0.12$ for $\mathrm{H}_{2}$ $\mathrm{PO}_{4}^{-}$, and $0.55-0.70$ for $\mathrm{SO}_{4}{ }^{2-}$.
Similarly, spathe area and root volume were highest when $\mathrm{NO}_{3}{ }^{-}$proportion ranged from $0.45-0.60, \mathrm{H}_{2} \mathrm{PO}_{4}{ }^{-}$proportion from $0.02-0.06$, and $\mathrm{SO}_{4}^{2-}$ proportion from $0.27-0.43$ (Fig. 2). The counter plots obtained with mixture analysis suggest that high proportions of $\mathrm{SO}_{4}{ }^{2-}$ combined with low proportions of $\mathrm{NO}_{3}{ }^{-}$and $\mathrm{H}_{2} \mathrm{PO}_{4}{ }^{-}$were detrimental for plant growth as fresh (Fig. 3) and dry weight (Fig. 4) were decreased.

These trends were comparable to those reported in anthurium by Dufour and Guérin (2005), indicating that a higher concentration of $\mathrm{N}, 8.9 \mathrm{mmol} \cdot \mathrm{L}^{-1}$, was associated with increased growth. In our study, in accordance with the mixture analysis, the high concentrations of $\mathrm{N}$ for optimum growth ranged from 10 to $16 \mathrm{meq} \cdot \mathrm{L}^{-1}\left(\mathrm{NO}_{3}{ }^{-}\right.$proportions from 0.50 to 0.80 ), which are considerably higher than those assessed by Dufour and Guérin (2005). Furthermore, the models also indicate that a low $\mathrm{NO}_{3}^{-}$proportion $(0.20$ 0.35 ) or concentration $\left(4.0-7.0 \mathrm{meq} \cdot \mathrm{L}^{-1}\right)$ may also be associated with growth enhancement, provided a relatively high $\mathrm{H}_{2} \mathrm{PO}_{4}^{-}$proportion is maintained, from 0.09 to $0.12(1.8-2.4$ meq. $\left.\mathrm{L}^{-1}\right)$, regardless of the high $\mathrm{SO}_{4}{ }^{2-}$ proportion or concentration (proportion from 0.55 to $0.70,11.0$ to $\left.14.0 \mathrm{meq} \cdot \mathrm{L}^{-1}\right)$. This may be because of the low $\mathrm{N}$ concentrations at which we observed optimum growth $\left(4.0-7.0 \mathrm{meq} \cdot \mathrm{L}^{-1}\right)$ were similar to the high concentrations reported by Dufour and Guérin (2005) and because of the greater supply of $\mathrm{P}$, a nutrient which is usually found to be deficient in epiphytic plants (Zotz, 2004).

Our results suggest that optimum growth of anthurium depended not only on $\mathrm{N}$ concentration, as it may be attained at either high or low $\mathrm{NO}_{3}^{-}$, but also on the proportion in which it is combined with $\mathrm{H}_{2} \mathrm{PO}_{4}^{-}$and $\mathrm{SO}_{4}{ }^{2-}$. Similarly, Takano (1987) suggested that the

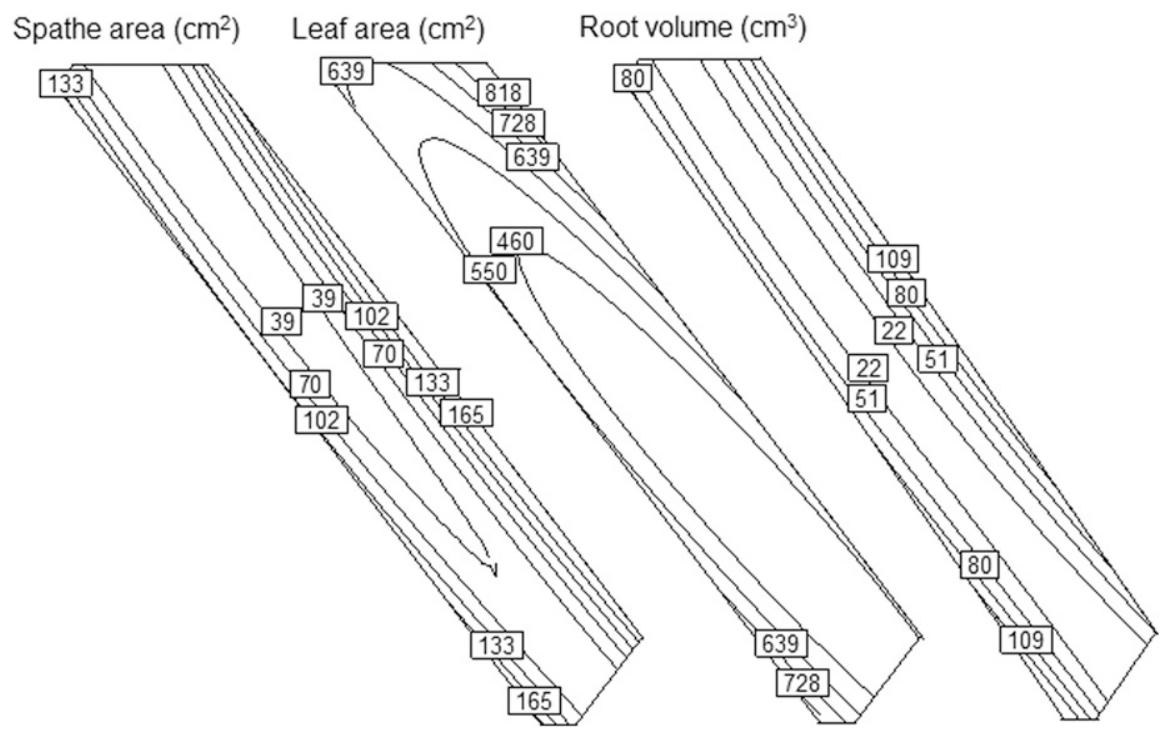

Fig. 2. Counter plots showing the effect of the $\mathrm{NO}_{3}{ }^{-}, \mathrm{H}_{2} \mathrm{PO}_{4}^{-}$, and $\mathrm{SO}_{4}{ }^{2-}$ proportion in the nutrient solution on spathe area, leaf area, and root volume in anthurium (Anthurium andraeanum Linden ex André) plants. 
$\mathrm{NO}_{3}^{-}, \mathrm{H}_{2} \mathrm{PO}_{4}^{-}$, and $\mathrm{SO}_{4}{ }^{2-}$ proportion and the proportion of $\mathrm{SO}_{4}{ }^{2-}$ and $\mathrm{H}_{2} \mathrm{PO}_{4}^{-}$may be useful in adjusting the uptake of $\mathrm{NO}_{3}{ }^{-}$, and thereby improving the quality of edible vegetables.
Nutrient status. Kleiber and Komosa (2010) reported that $\mathrm{N}, \mathrm{P}$, and $\mathrm{S}$ in anthurium leaves should range from 907 to 1329,94 to 145 , and 69 to $141 \mathrm{mmol} \cdot \mathrm{kg}^{-1}$, respectively. In the present study, shoot and root $\mathrm{N}, \mathrm{P}$, and
Shoot fresh weight (g) Root fresh weight (g) Total fresh weight (g)

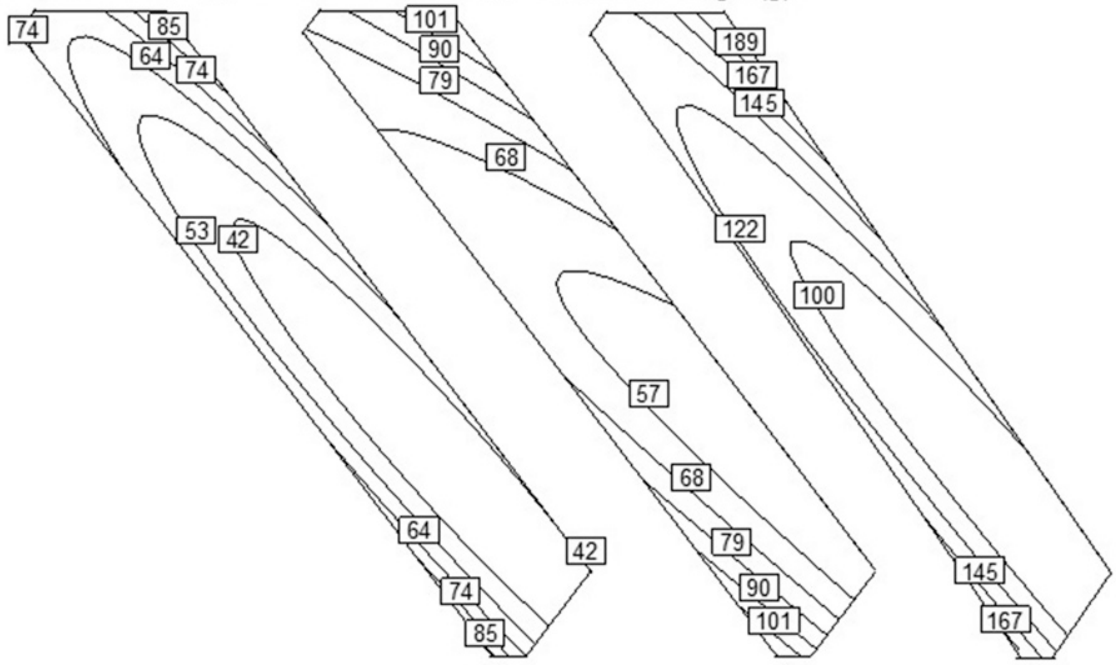

Fig. 3. Counter plots showing the effect of the $\mathrm{NO}_{3}{ }^{-}, \mathrm{H}_{2} \mathrm{PO}_{4}^{-}$, and $\mathrm{SO}_{4}{ }^{2-}$ proportion in the nutrient solution on shoot, root, and total fresh weight in anthurium (Anthurium andraeanum Linden ex André) plants.

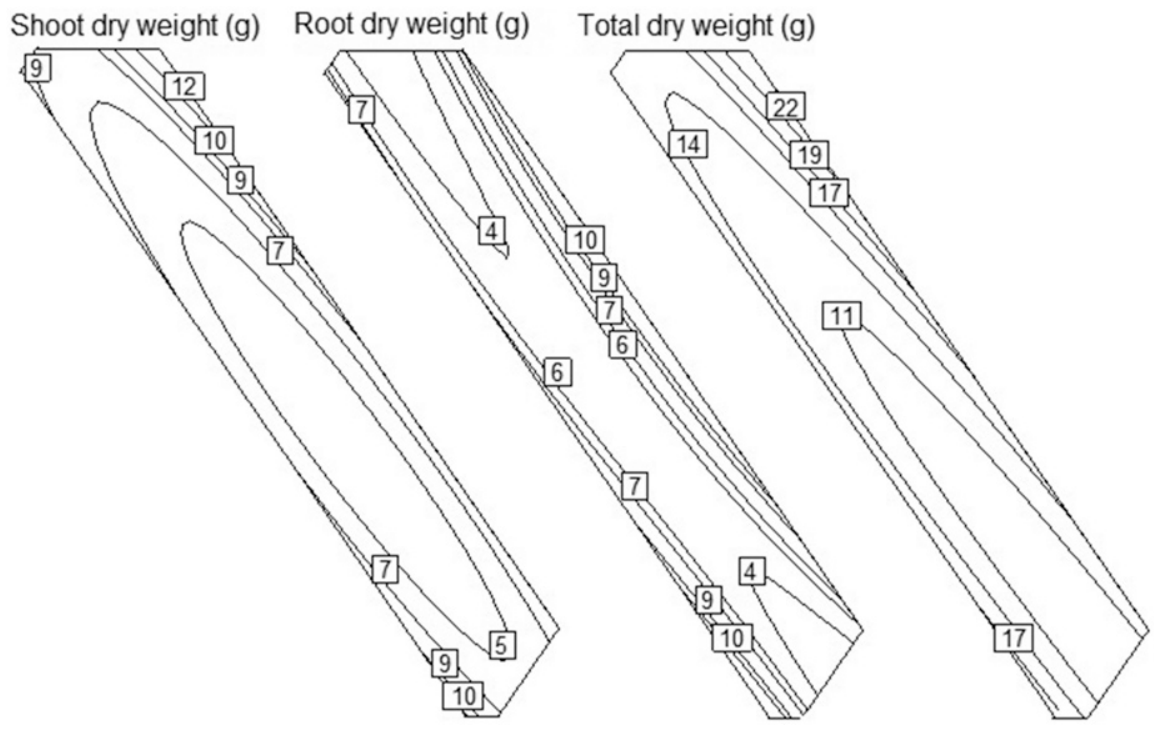

Fig. 4. Counter plots showing the effect of the $\mathrm{NO}_{3}{ }^{-}, \mathrm{H}_{2} \mathrm{PO}_{4}{ }^{-}$, and $\mathrm{SO}_{4}{ }^{2-}$ proportion in the nutrient solution on shoot, root, and total dry weight in anthurium (Anthurium andraeanum Linden ex André) plants.
$\mathrm{S}$ concentration were significantly affected by the $\mathrm{NO}_{3}{ }^{-}: \mathrm{H}_{2} \mathrm{PO}_{4}{ }^{-}: \mathrm{SO}_{4}{ }^{2-}$ proportions (Table 4); in the roots, N, P, and $\mathrm{S}$ were similar to those reported for the leaves by Kleiber and Komosa (2010), whereas in the shoot they were within those ranges only for some treatments (Table 4). Our results were similar to those reported by Chang et al. (2012) indicating that high N (7.5 and 11.3 meq $\cdot \mathrm{L}^{-1}$ ) was associated with improved dry weight, leaf area, and number of flowers in anthurium, when compared with plants fertigated with lower or higher $\mathrm{N}$ levels (5.6 and 15.0 meq $\cdot \mathrm{L}^{-1}$ ).

Increasing the proportions of $\mathrm{NO}_{3}^{-}, \mathrm{H}_{2}$ $\mathrm{PO}_{4}{ }^{-}$and $\mathrm{SO}_{4}{ }^{2-}$ resulted in increased concentration of $\mathrm{N}, \mathrm{P}$, and $\mathrm{S}$ in plants. Plants fed with solutions containing the highest $\mathrm{SO}_{4}{ }^{2-}$ proportions resulted with the highest $\mathrm{S}$ content at a whole plant level, except when fed with high $\mathrm{H}_{2} \mathrm{PO}_{4}^{-}\left(\mathrm{NO}_{3}{ }^{-}: \mathrm{H}_{2} \mathrm{PO}_{4}^{-}: \mathrm{SO}_{4}{ }^{2-}\right.$ proportion of 0.20:0.12:0.68). A similar trend in $\mathrm{SO}_{4}{ }^{2-}$ uptake was reported by López et al. (2002) in tomato seedlings (Solanum lycopersicum L.), which is in line with reports by Rennenberg (1984), suggesting that avoidance of $\mathrm{S}$ uptake is not a mechanism used by plants under external or internal $\mathrm{SO}_{4}{ }^{2-}$ excess, being the influx of excess $\mathrm{S}$ was more probable than restricted uptake (Rennenberg, 1984).

Dufour and Clairon (1997) reported that an adequate supply of $\mathrm{N}$ for anthurium is between 7.5 and $8.9 \mathrm{meq} \cdot \mathrm{L}^{-1}$ as lower concentrations may reduce growth, affect the length of the vegetative phase, and produce flowers of low quality. In our present study, we observed that anthurium plants may grow even at lower $\mathrm{NO}_{3}{ }^{-}$proportion and concentration, 0.20 and 4.0 meq. $\mathrm{L}^{-1}$, respectively, provided $\mathrm{H}_{2} \mathrm{PO}_{4}^{-}$is increased to counteract the increase in $\mathrm{SO}_{4}{ }^{2-}$.

Anion interactions. Fageria and Oliveira (2014) suggested that information focused on the interactions among nutrients is of utmost importance when formulating a balanced supply of fertilizers to cultivated plants. Interactions among nutrients occur when the supply of one nutrient influences the uptake and utilization of another one (Fageria, 2001). In the present study, the interactions among the anions resulted in consistent trends and were modeled with mixture analysis (Table 5). The explored area showed that $\mathrm{N}$ and $\mathrm{S}$ tended to concentrate, for both, shoots (Fig. 5) and roots (Fig. 6), when plants

Table 4. Effect of the $\mathrm{NO}_{3}^{-}: \mathrm{H}_{2} \mathrm{PO}_{4}^{-}: \mathrm{SO}_{4}{ }^{2-}$ proportion in the nutrient solutions on the concentration of nitrogen (N), phosphorus (P), and sulfur (S) in shoots and roots of anthurium (Anthurium andraeanum Linden ex André) plants.

\begin{tabular}{|c|c|c|c|c|c|c|c|c|}
\hline \multicolumn{3}{|c|}{ Nutrient solution } & \multicolumn{3}{|c|}{ Shoot } & \multicolumn{3}{|c|}{ Root } \\
\hline $\mathrm{NO}_{3}{ }^{-}$ & $\mathrm{H}_{2} \mathrm{PO}_{4}^{-}$ & $\mathrm{SO}_{4}^{2-}$ & $\mathrm{N}$ & $\mathrm{P}$ & $\mathrm{S}$ & $\mathrm{N}$ & $\mathrm{P}$ & $\mathrm{S}$ \\
\hline$\overline{0.43}$ & 0.05 & 0.53 & $1342 \mathrm{ab}$ & $52.4 \mathrm{bc}$ & $63.7 \mathrm{a}$ & $1325 \mathrm{bc}$ & $150 \mathrm{~cd}$ & $91.4 \mathrm{bc}$ \\
\hline 0.78 & 0.12 & 0.10 & $1419 a b$ & $56.7 \mathrm{bc}$ & $45.8 \mathrm{bc}$ & $1644 \mathrm{a}$ & $230 \mathrm{ab}$ & $85.1 \mathrm{c}$ \\
\hline 0.20 & 0.12 & 0.68 & $1231 \mathrm{~b}$ & $111.0 \mathrm{a}$ & $36.4 \mathrm{c}$ & $1242 \mathrm{c}$ & $252 \mathrm{a}$ & $89.0 \mathrm{bc}$ \\
\hline 0.49 & 0.12 & 0.39 & $1500 \mathrm{a}$ & $61.8 \mathrm{~b}$ & $49.6 \mathrm{abc}$ & $1431 a b c$ & $179 b c$ & $80.5 \mathrm{c}$ \\
\hline 0.28 & 0.02 & 0.70 & $1338 \mathrm{ab}$ & $47.3 \mathrm{~b}$ & $60.6 \mathrm{ab}$ & $1238 \mathrm{c}$ & $88 \mathrm{e}$ & $106.0 \mathrm{ab}$ \\
\hline
\end{tabular}




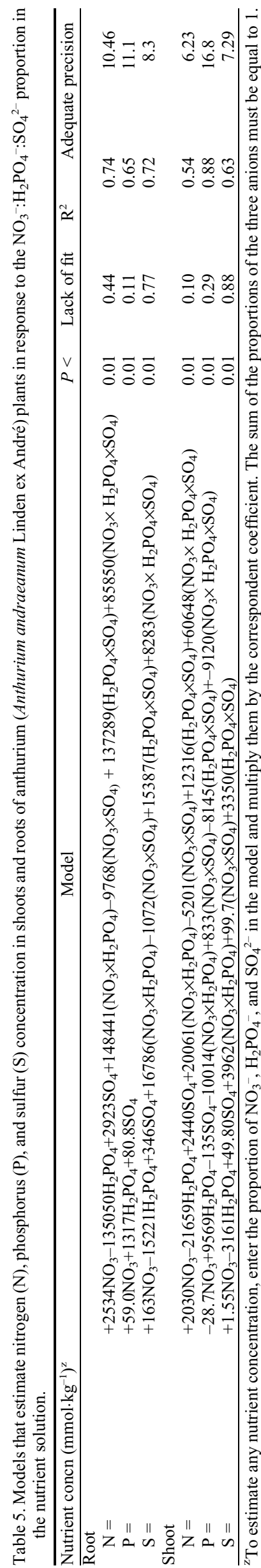

HortScience Vol. 52(11) November 2017 were fertigated with solutions containing high proportions of $\mathrm{NO}_{3}^{-}(0.55-0.80)$ and $\mathrm{SO}_{4}{ }^{2-}(0.40-0.70)$. Phosphorus concentration in the shoots was higher when plants were fertigated with solutions of low (as long as $\mathrm{NO}_{3}{ }^{-}$was at proportions of 0.50 and $\mathrm{SO}_{4}{ }^{2-}$ at 0.35 ) or high $\mathrm{H}_{2} \mathrm{PO}_{4}^{-}$proportions (as long as $\mathrm{SO}_{4}{ }^{2-}$ proportion was at 0.35 ) (Fig. 5). In the roots, increasing $\mathrm{P}$ concentrations were associated with increasing $\mathrm{H}_{2} \mathrm{PO}_{4}^{-}$proportions (Fig. 6).

Nitrogen is a constituent of all the amino acids whereas $\mathrm{S}$ is a constituent in two of them, cysteine and methionine; therefore, as $\mathrm{N}$ and $\mathrm{S}$ are both part of proteins, there is a close relationship between their assimilation (Hawkesford et al., 2012). The uptake of $\mathrm{N}$ and $\mathrm{S}$ is well coordinated, in that, for example, a deficiency of one may cause a decrease in the assimilation of the other one (Kopriva and Rennenberg, 2004; Kruse et al., 2007). A close relationship between $\mathrm{N}$ and $\mathrm{S}$ has been reported in several plant species; for example, in wheat (Triticum aestivum L.) (Salvagiotti et al., 2009) and legumes (Scherer, 2001), increasing S

\section{Shoot $\left(\mathrm{mmol} \mathrm{kg}^{-1}\right)$}

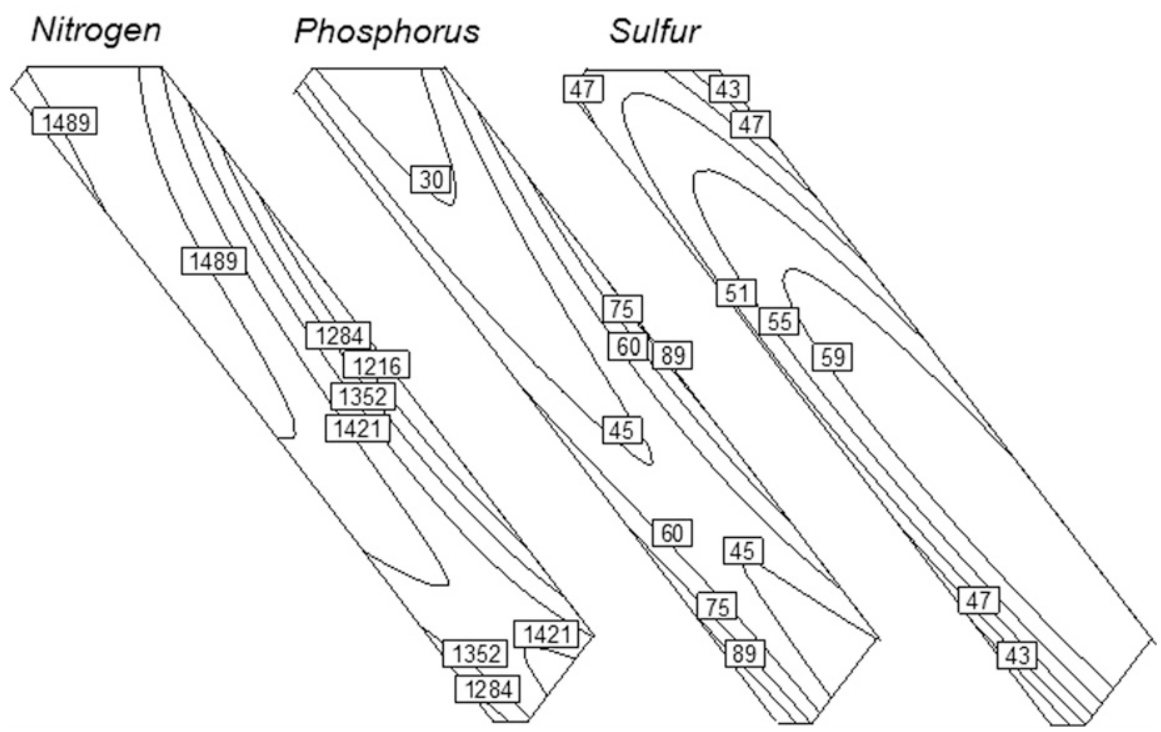

Fig. 5. Counter plots showing the effect of the $\mathrm{NO}_{3}{ }^{-}, \mathrm{H}_{2} \mathrm{PO}_{4}^{-}$, and $\mathrm{SO}_{4}{ }^{2-}$ proportion in the nutrient solution in shoot nitrogen $(\mathrm{N})$, phosphorus $(\mathrm{P})$, and sulfur $(\mathrm{S})$ concentration in anthurium (Anthurium andraeanum Linden ex André) plants.

\section{Root $(\mathrm{mmol} \mathrm{kg}-1)$}

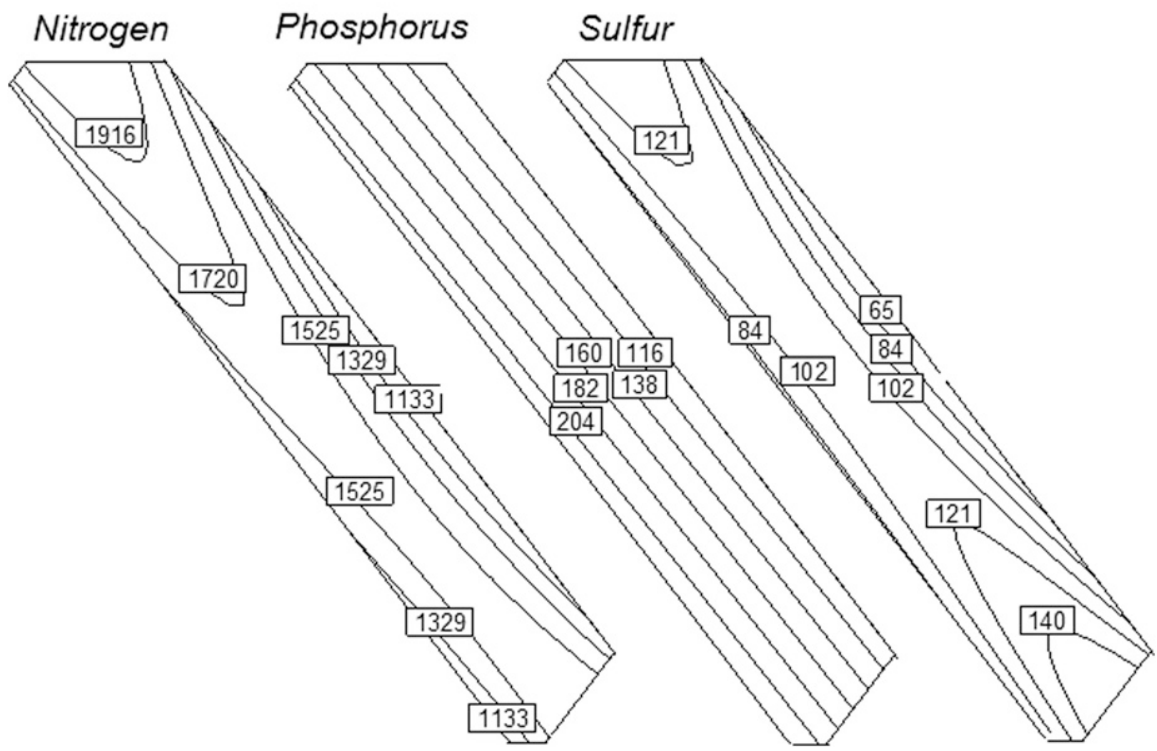

Fig. 6. Counter plots showing the effect of the $\mathrm{NO}_{3}{ }^{-}, \mathrm{H}_{2} \mathrm{PO}_{4}{ }^{-}$, and $\mathrm{SO}_{4}{ }^{2-}$ proportion in the nutrient solution in root nitrogen $(\mathrm{N})$, phosphorus $(\mathrm{P})$, and sulfur $(\mathrm{S})$ concentration in anthurium (Anthurium andraeanum Linden ex André) plants. 


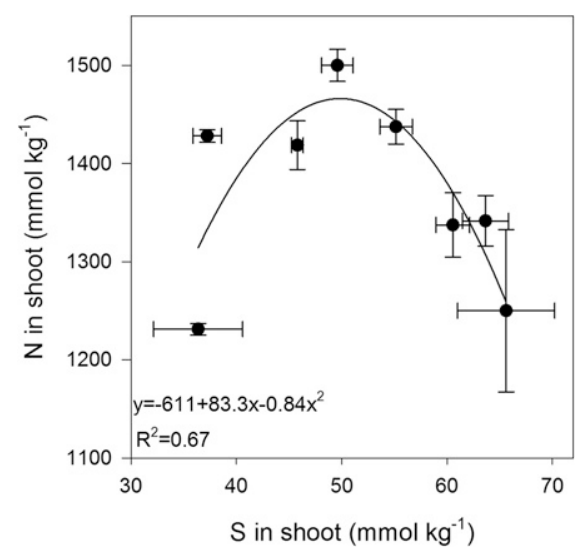

Fig. 7. Relationship between the concentration of nitrogen $(\mathrm{N})$ and sulfur $(\mathrm{S})$ in shoots of anthurium (Anthurium andraeanum Linden ex André) plants. fertilization under $\mathrm{S}$ deficiency conditions resulted in improved $\mathrm{N}$ use efficiency and uptake; however, in tomato and cabbage (Brassica oleracea var. capitata L.), $\mathrm{N}$ uptake was inhibited by high concentrations of $\mathrm{SO}_{4}{ }^{2-}$ (Takano, 1987). Sulfur deficiency in wheat has also been related to lower sulfuramino acids content and reduced yield (Järvan et al., 2008).

In the present study, the association between $\mathrm{N}$ and $\mathrm{S}$ was also evident because at low shoot concentration, increasing $\mathrm{S}$ resulted in increasing shoot $\mathrm{N}$ concentration (Fig. 7); however, further $\mathrm{S}$ increments in the shoot were associated with a decrease in $\mathrm{N}$ (Fig. 7). The decreased $\mathrm{N}$ concentration as a result of the high $\mathrm{S}$ concentration in the shoots may explain the potentially toxic effects of $\mathrm{SO}_{4}{ }^{2-}$ observed in our present study, as indicated by

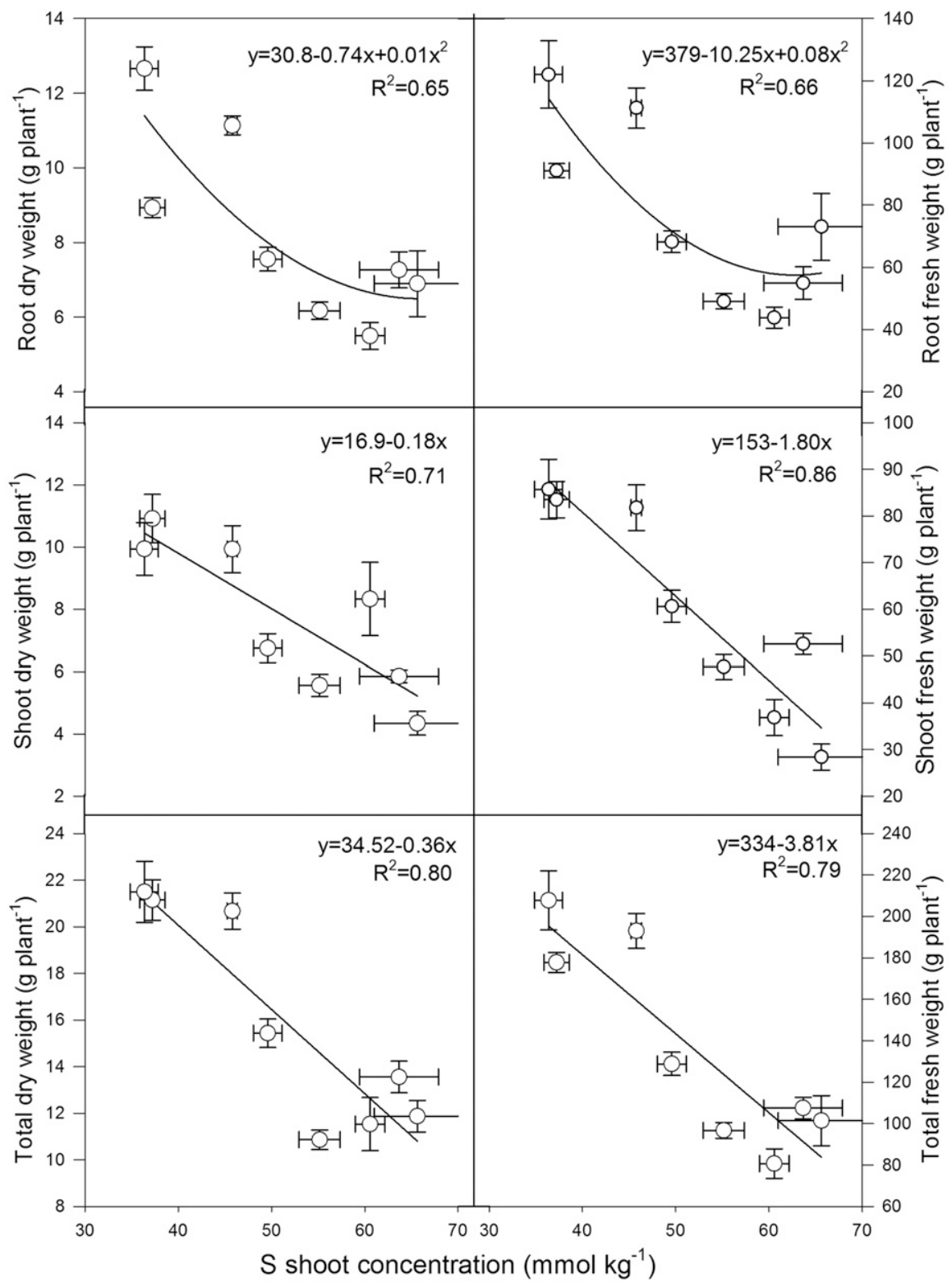

Fig. 8. Correlation between shoot and root sulfur concentration on fresh weight and dry weight of shoots in anthurium (Anthurium andraeanum Linden ex André) plants. the lower root, shoot, and total plant fresh and dry weight at high $\mathrm{S}$ concentrations (Fig. 8).

Nitrogen and $\mathrm{S}$ in shoots and roots were highest when the proportion of the respective anion increased in the nutrient solution (Figs. 5 and 6); furthermore, $\mathrm{SO}_{4}{ }^{2-}$ uptake rate was maintained as indicated by the high $\mathrm{S}$ concentration in the shoots and roots at high $\mathrm{SO}_{4}{ }^{2-}$ proportions (Figs. 5 and 6) whereas shoot $\mathrm{S}$ concentration was low even at high $\mathrm{SO}_{4}{ }^{2-}$ proportions as long as the proportion of $\mathrm{H}_{2} \mathrm{PO}_{4}{ }^{-}$in the nutrient solution and the concentration of $\mathrm{P}$ in the shoot were high (Fig. 5). Plants fertigated with nutrient solutions containing $\mathrm{NO}_{3}{ }^{-}, \mathrm{H}_{2} \mathrm{PO}_{4}^{-}$, and $\mathrm{SO}_{4}{ }^{2-}$ at proportions of $0.20: 0.12: 0.68$ (Table 4) resulted in growth promotion (Table 2).

Anthurium plants fertigated with solutions containing the highest proportion of $\mathrm{H}_{2} \mathrm{PO}_{4}^{-}$resulted in shoots and roots with the lowest $\mathrm{S}$ concentration despite some of those nutrient solutions were formulated with very high $\mathrm{SO}_{4}{ }^{2-}$ proportions (Table 2), suggesting that high $\mathrm{H}_{2} \mathrm{PO}_{4}^{-}$proportions counteracted the uptake of $\mathrm{SO}_{4}{ }^{2-}$. This hypothesis is supported by reports indicating that $\mathrm{SO}_{4}{ }^{2-}$-induced salinity has a more negative impact on the growth of Brassica rapa L. at lower concentrations of $\mathrm{P}$ (Reich et al., 2017), which also suggests that higher $\mathrm{H}_{2} \mathrm{PO}_{4}^{-}$proportion may reduce the negative impact of $\mathrm{SO}_{4}{ }^{2-}$ on $\mathrm{H}_{2} \mathrm{PO}_{4}{ }^{-}$ uptake.

Internal $N / S$ and $S / P$ proportion. High $\mathrm{S}$ concentrations in plant tissues (Fig. 8) affected the internal $\mathrm{N} / \mathrm{S}$ and $\mathrm{S} / \mathrm{P}$ proportions. Our results showed that a higher internal $\mathrm{N} / \mathrm{S}$ proportion and a lower internal $\mathrm{S} / \mathrm{P}$ proportion were associated with higher shoot fresh weight (Fig. 9). Similarly, increasing $\mathrm{S}$ shoot concentration was associated with poor growth, which is related to its effect on the reduction in the N/ $S$ proportion and in the increase in the $S / P$ proportion.

At a whole plant level, Cram (1990) reported that the N/S proportion for optimum growth in plants is 20/1 whereas for clover (Trifolium repens $\mathrm{L}$.), the optimum S/P proportion ranged from $0.81-0.93$ (Morton et al., 1998). In the present study, optimum growth of anthurium plants was observed when the $\mathrm{N} / \mathrm{S}$ and $\mathrm{S} / \mathrm{P}$ proportion ranged from $31 / 1$ to $38 / 1$ and $0.33 / 1$ to $0.80 / 1$, respectively (Fig. 9). These results suggest that for optimum growth, nutrient solutions must contain high proportions of $\mathrm{NO}_{3}{ }^{-}$and low $\mathrm{SO}_{4}{ }^{2-}$ for the plant to have a high internal $\mathrm{N} / \mathrm{S}$ proportion. Alternatively, a high proportion of $\mathrm{SO}_{4}{ }^{2-}$ in the nutrient solution may render acceptable plant growth as long as the proportion of $\mathrm{H}_{2} \mathrm{PO}_{4}^{-}$is higher, for the plant to maintain a low internal $\mathrm{S} / \mathrm{P}$ proportion.

Effect of the external anion proportion on $N, P$, and $S$ allocation. The allocation of $\mathrm{N}, \mathrm{P}$, and $\mathrm{S}$ within the plant was affected by the $\mathrm{NO}_{3}^{-}: \mathrm{H}_{2} \mathrm{PO}_{4}^{-}: \mathrm{SO}_{4}^{2-}$ proportion. Nitrogen was predominantly diverted to the 
roots in control plants whereas the allocation to the shoots increased in plants fertigated with lower proportions of $\mathrm{NO}_{3}{ }^{-}$ (Fig. 10). The relatively higher allocation of $\mathrm{N}$ to the shoots of plants under limited $\mathrm{NO}_{3}{ }^{-}$supply suggests that this nutrient was transported from the roots to promote shoot growth under insufficiency conditions. Despite the increased S concentration in plant tissues with increasing $\mathrm{SO}_{4}{ }^{2-}$ proportions (Table 4), most of the $\mathrm{S}$ was allocated to the roots (Fig. 10); this is in agreement with results reported for tomato seedlings, in that increasing $\mathrm{SO}_{4}{ }^{2-}$ supply to $\mathrm{S}$-deficient plants results in increased transport rate of $\mathrm{SO}_{4}{ }^{2-}$ to the shoot; however, when the supply of $\mathrm{SO}_{4}{ }^{2-}$ was high, the transport rate did not increase (López et al., 2002).

In the present study, when anthurium was fed with both high $\mathrm{SO}_{4}{ }^{2-}$ and high $\mathrm{H}_{2} \mathrm{PO}_{4}^{-}$, even more $\mathrm{S}$ was allocated to the roots than to the shoots (Fig. 10), as observed in plants fertigated with solutions with a $\mathrm{NO}_{3}^{-}: \mathrm{H}_{2}$ $\mathrm{PO}_{4}{ }^{-}: \mathrm{SO}_{4}{ }^{2-}$ proportion of $0.20: 0.12: 0.68$. The restricted $\mathrm{S}$ translocation to the shoot

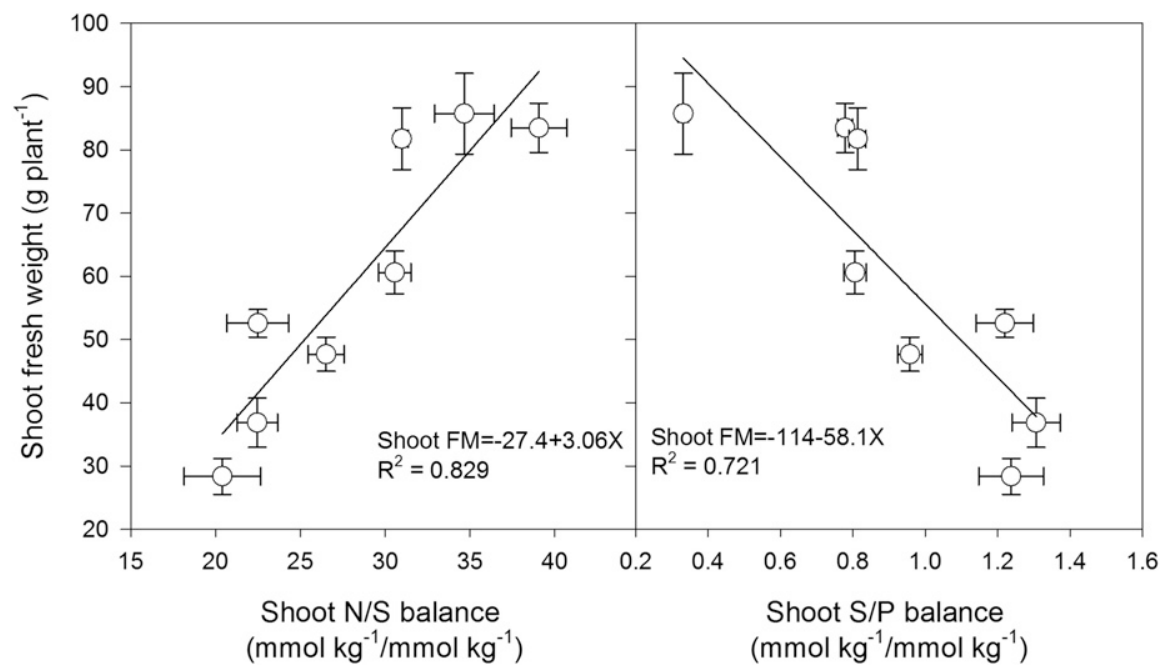

Fig. 9. Correlation between shoot internal nitrogen/sulfur (N/S), sulfur/phosphorus (S/P) proportion, and shoot fresh weight in anthurium (Anthurium andraeanum Linden ex André) plants.
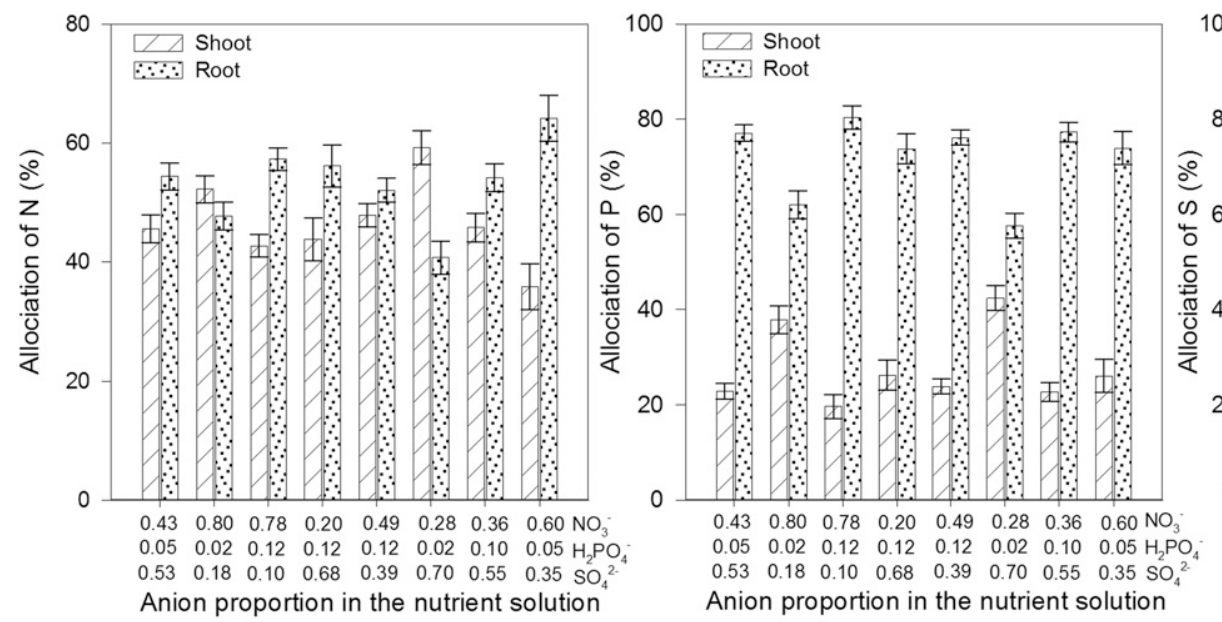

a) avoiding the transport of $\mathrm{S}$ to the shoot

(Fig. 10),

b) decreasing $\mathrm{SO}_{4}{ }^{2-}$ intake (Table 4),

c) maintaining a favorable internal $\mathrm{N} / \mathrm{S}$ proportion (Fig. 9),

d) maintaining a favorable internal $\mathrm{S} / \mathrm{P}$ proportion (Fig. 9),

e) increasing $\mathrm{P}$ tissue concentration as a result of high proportions of $\mathrm{H}_{2} \mathrm{PO}_{4}^{-}$in the nutrient solution.

Anion uptake selectivity. In spite of the differences in nutrient concentration, plant internal $\mathrm{NO}_{3}{ }^{-}: \mathrm{H}_{2} \mathrm{PO}_{4}{ }^{-}: \mathrm{SO}_{4}{ }^{2-}$ proportion was unaffected by the external anion ratios as the internal nutrient ratios in the shoots and roots were located in a very specific area

explain the increased growth of these plants as lower $\mathrm{S}$ concentrations was associated (Fig. 8).

These results suggest that anthurium plants were able to cope with high $\mathrm{SO}_{4}{ }^{2-}$ in the nutrient solution by:
(Fig. 11). This suggests that anthurium regulates the accumulation of anions based on its internal demands. Steiner (1973) reported similar trends in tomato, concluding that, regardless of the ratio in the nutrient solution, this species has a strong selective capacity for cation and anion uptake at a given ratio. In the present study, the location of the area for the internal anion ratio shown in Fig. 11 suggests that anthurium was highly selective to exclude $\mathrm{SO}_{4}{ }^{2-}$ as this nutrient was at much lower concentration than that of the external solutions. Similarly, anthurium plants were able to adjust their uptake of $\mathrm{NO}_{3}{ }^{-}$as the internal proportion was maintained at relatively high concentration regardless of the external ratio (Fig. 11). By contrast, the uptake of $\mathrm{H}_{2}$ $\mathrm{PO}_{4}^{-}$was not very selective, as the internal and external ratios were very similar (Fig. 11).

In conclusion, increased growth of anthurium plants was attained at either high or low $\mathrm{NO}_{3}{ }^{-}$proportions. Furthermore, we suggest that at low $\mathrm{NO}_{3}^{-}$, the high $\mathrm{H}_{2} \mathrm{PO}_{4}^{-}$ counteracted the deleterious effect of high $\mathrm{SO}_{4}{ }^{2-}$ proportions on $\mathrm{P}$ tissue concentration. Increasing $\mathrm{S}$ concentration in plant tissues was associated with reduced growth; however, excess $\mathrm{SO}_{4}{ }^{2-}$ uptake was prevented when $\mathrm{P}$ status in the plants was increased when $\mathrm{H}_{2} \mathrm{PO}_{4}^{-}$proportions were augmented, resulting in lower $\mathrm{S}$ tissue concentrations and improved growth. Our results also suggest that anthurium plants were able to cope with high $\mathrm{SO}_{4}{ }^{2-}$ when $\mathrm{H}_{2} \mathrm{PO}_{4}{ }^{-}$in the nutrient solution was increased through limiting its transport to the shoot, which in turn resulted in favorable $\mathrm{N} / \mathrm{S}$ and $\mathrm{S} / \mathrm{P}$ internal proportions. The internal anion proportion was unaffected by the $\mathrm{NO}_{3}{ }^{-}: \mathrm{H}_{2} \mathrm{PO}_{4}^{-}: \mathrm{SO}_{4}{ }^{2-}$ proportions in the nutrient solution, demonstrating that anthurium possesses a high selective capacity for nutrient uptake and allocation/ partitioning.

Fig. 10. Relative distribution of nitrogen $(\mathrm{N})$, phosphorus (P), and sulfur (S) in shoots and roots of anthurium (Anthurium andraeanum Linden ex André) plants. 

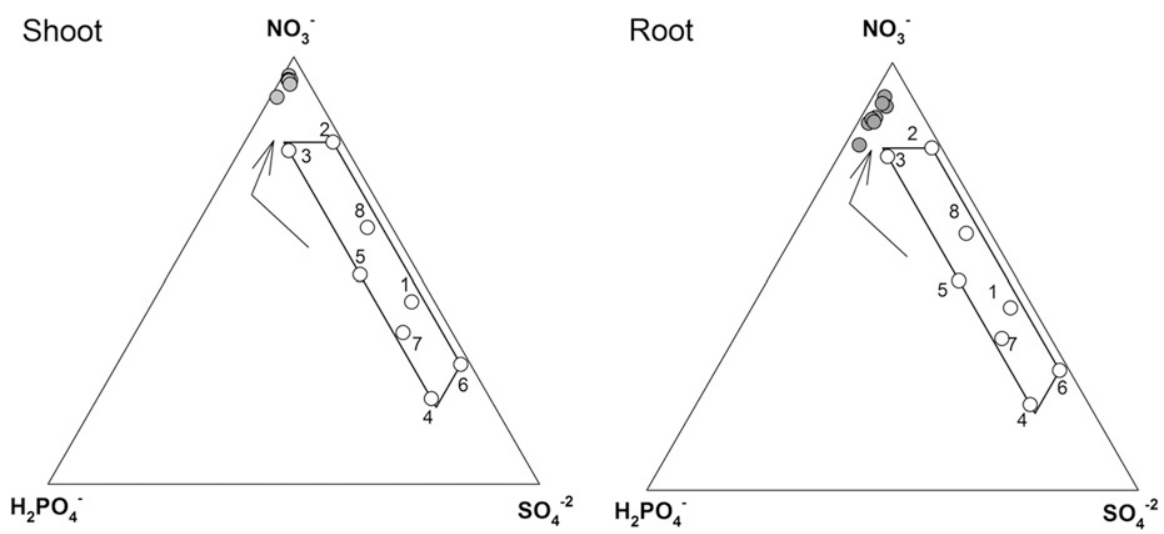

Fig. 11. Relationship between the $\mathrm{NO}_{3}^{-}, \mathrm{H}_{2} \mathrm{PO}_{4}^{-}$, and $\mathrm{SO}_{4}{ }^{2-}$ proportion in the nutrient solution (white symbols) with the $\mathrm{NO}_{3}^{-}, \mathrm{H}_{2} \mathrm{PO}_{4}^{--}$, and $\mathrm{SO}_{4}{ }^{2-}$ proportion (gray symbols) in the shoot and root of anthurium (Anthurium andraeanum Linden ex André) plants. Numbers indicate the treatment nutrient solution as shown in Table 1. Data for shoot and root balance calculated on meq $\mathrm{kg}^{-1}$.

\section{Literature Cited}

Chang, K.H., R.Y. Wu, G.P. Chang, T.F. Hsieh, and R.S. Chung. 2012. Effects of nitrogen concentration on growth and nutrient uptake of Anthurium andraeanum Lind. cultivated in coir under different seasonal conditions. HortScience 47:515-521.

Chang, K.H., R.Y. Wu, K.C. Chuang, T.F. Hsieh, and R.S. Chung. 2010. Effects of chemical and organic fertilizers on the growth, flower quality and nutrient uptake of Anthurium andreanum, cultivated for cut flower production. Sci. Hort. 125(3):434-441.

Conover, C.A. and R.J. Henny. 1995. Lowering N and $\mathrm{K}$ rates improves anthurium growth and flowering. Proc. Annu. Meet. Fla. State Hort. Soc. 108:5-9.

Cram, W.J. 1990. Uptake and transport of sulphate, p. 3-11. In: H. Rennenberg (ed.). Sulphur nutrition and assimilation in higher plants. SPB Academic Publishing, The Hague, The Netherlands.

Ding, Y., W. Luo, and G. Xu. 2006. Characterisation of magnesium nutrition and interaction of magnesium and potassium in rice. Ann. Appl. Biol. 149:111-123.

Dufour, L. and M. Clairon. 1997. Advances in fertilization of Anthurium hybrid in Guadeloupe (FWI). Intl. Symp. Growing Media Plant Nutr. Hort. 450:433-437.
Dufour, L. and V. Guérin. 2005. Nutrient solution effects on the development and yield of $A n-$ thurium andreanum Lind. in tropical soilless conditions. Sci. Hort. 105:269-282.

Fageria, N.K. and J.P. Oliveira. 2014. Nitrogen, phosphorus and potassium interactions in upland rice. J. Plant Nutr. 37(10):1586-1600.

Fageria, V.D. 2001. Nutrient interactions in crop plants. J. Plant Nutr. 24:1269-1290.

Hawkesford, M., W. Horst, T. Kichey, J. Schjoerring, I.S. Moller, and P. White. 2012. Functions of macronutrients, p. 135-189. In: P. Marschner (ed.). Marschner's mineral nutrition of higher plants. Academic Press.

Hull, D.L. and R.J. Henny. 1995. Anthurium and Aglaonema production in Dade county, Florida. Proc. Annu. Meet. Fla. State Hort. Soc. 108:4-5.

Jakobsen, S.T. 1993. Interaction between plant nutrients: III. Antagonism between potassium, magnesium and calcium. Acta Agr. Scand. Sec. B. $43: 1-5$.

Järvan, M., L. Edesi, A. Adamson, L. Lukme, and A. Akk. 2008. The effect of sulphur fertilization on yield, quality of protein and baking properties of winter wheat. J. Agron. Res. 6:459-469.

Kleiber, T. and A. Komosa. 2010. Guide values for anthurium (Anthurium cultorum Birdsey) grown in expanded clay. J. Plant Nutr. 33(10):15061518.
Kopriva, S. and H. Rennenberg. 2004. Control of sulphate assimilation and glutathione synthesis: Interaction with $\mathrm{N}$ and $\mathrm{C}$ metabolism. $\mathrm{J}$. Expt. Bot. 55:1831-1842.

Kruse, J., S. Kopriva, R. Hänsch, G.J. Krauss, R.R. Mendel, and H. Rennenberg. 2007. Interaction of sulfur and nitrogen nutrition in tobacco (Nicotiana tabacum) plants: Significance of nitrogen source and root nitrate reductase. Plant Biol. 9:638-646.

Li, Y. and M. Zhang. 2002. Effects of urea and nitric acid on water and medium quality and on response of anthurium. HortTechnology $12: 131-134$.

López, J., C.I. Bell, N. Tremblay, M. Dorais, and A. Gosselin. 2002. Uptake and translocation of sulphate in tomato seedlings in relation to sulphate supply. J. Plant Nutr. 25:1471-1485.

Morton, J.D., A.G. Sinclair, J.D. Morrison, L.C. Smith, and K.G. Dodds. 1998. Balanced and adequate nutrition of phosphorus and sulphur in pasture. N. Z. J. Agr. Res. 41:487-496.

Reich, M., T. Aghajanzadeh, J. Helm, S. Parmar, M.J. Hawkesford, and L.J. De Kok. 2017. Chloride and sulfate salinity differently affect biomass, mineral nutrient composition and expression of sulfate transport and assimilation genes in Brassica rapa. Plant Soil 411:1-14.

Rennenberg, H. 1984. The fate of excess sulfur in higher plants. Annu. Rev. Plant Physiol. 35:121-153.

Salvagiotti, F., J.M. Castellarín, D.J. Miralles, and H.M. Pedrol. 2009. Sulfur fertilization improves nitrogen use efficiency in wheat by increasing nitrogen uptake. Field Crops Res. 113:170-177.

Scherer, H.W. 2001. Sulphur in crop production. Eur. J. Agron. 14(2):81-111.

Steiner, A.A. 1968. Soiless culture. In the fertilization of potted crops. Proc. 6th Colloq. Intl. Potash Inst., Berne, Switzerland. p. 321-324.

Steiner, A.A. 1973. Selective capacity of tomato plants for ions in a nutrient solution. Proc. Intl. Congr. Soilless Cult., 3d, Sassari

Takano, T. 1987. Physiology: On an anionic balance in plant inorganic nutrition. J. Plant Nutr. 10:1605-1611.

Zotz, G. 2004. The resorption of phosphorus is greater than that of nitrogen in senescing leaves of vascular epiphytes from lowland Panama. J. Trop. Ecol. 20:693-696.

Zotz, G. and P. Hietz. 2001. The physiological ecology of vascular epiphytes: Current knowledge, open questions. J. Expt. Bot. 52:20672078 . 